\title{
MONITORING OF SOME DISSOLVED HEAVY METALS IN SURFACE WATERS OF NORTH-WEST CROATIA FROM YEAR 2016 TO 2018
}

\author{
Patricia Mlinarić1, Nikola Sakač ${ }^{1 *}$, Anita Ptiček Siročić1 Irena Tomiek $^{2}$ \\ ${ }^{1}$ University of Zagreb, Faculty of Geotechnical Engineering, Hallerova aleja 7, 42000 Varaždin, Croatia \\ ${ }^{2}$ Croatian Institute of Public Health in Varaždin county, I. Meštrovića 1/11, 42000 Varaždin, Croatia \\ *E-mail of corresponding author:nsakac@gfv.unizg.hr
}

\begin{abstract}
Heavy metals have a negative impact on environment and wildlife. In waters, heavy metals appear in two forms, as dissolved and bioavailable; and as solid and non-soluble. We monitored the concentration of dissolved copper, nickel, manganese and iron in water samples at five river locations of north-west Croatia from 2016 to 2018. Concentrations of dissolved nickel measured at Melačka river, near Vularija in Međimurje county and HE Čakovec dam, near Štefanec in Međimurje county were below $5 \mu \mathrm{g} / \mathrm{l}$ and could be considered as not polluted. Concentrations of dissolved copper measured at Plitvica river, near Zbela in Varaždinska county and Horvatska, near Veliko Trgovišće in Krapinsko-Zagorska county were mostly below $5 \mu \mathrm{g} / \mathrm{l}$ and could be considered as not polluted. At Kosteljina river near Jalšje at the Krapinsko-Zagorska county concentrations of dissolved copper were mostly below $5 \mu \mathrm{g} /$; concentrations of dissolved manganese and iron were higher especially during second part of the year, with some fluctuations. For this reason, Kosteljina river could be considered as medium polluted.
\end{abstract}

Keywords: heavy metals, pollution, north-west Croatia rivers.

\begin{tabular}{c}
\hline Received: 23.9 .2020$. / Accepted: 20.10 .2020$. \\
Published online: 7.12.2020. \\
\hline \\
Original scientific paper \\
https://doi.org/10.37023/ee.7.2.2
\end{tabular}

\section{INTRODUCTION}

Heavy metals, in general, have a negative impact on environment and wildlife. The cycle of the heavy metals in aquatic systems is complex and includes physical, chemicals and biological processes at three different parts: water-biota-sediment. (Jordana \& Batista Piera 2004) The intensity of their circulation is unequal during the year and mostly depends on the seasonal changes, climate conditions and biological activity. (Fergusson 1991) The translation of heavy metals from one state to another depends on their entering state and concentration, but also on the constitution of water. Since heavy metals are divided on dissolved (hydrated ions, complex with organic and inorganic ligands), colloidal and adsorbed on the particulate matters, their potential bioavailability/toxicity and removing possibility will depend on chemical bonds and physical forms of the metals.(Merian et al. 2004)

Activity mechanisms of dissolved heavy metals with particle matter and biota are regulated with different physical-chemical processes like complexation, adsorption/desorption, dissociation and diffusion (Jordana \& Batista Piera 2004). Adsorption of heavy metals on particle matter, which is then precipitated, consequently causes an increased concentration in sediment and aquatic life (fishes and shells). (Wood 1974) When adsorption capacity of the sediment is saturated, the level of heavy metals is increasing in water. It is important to note that the sediment is the most important reservoir in the aquatic systems and it represents a danger of re-activation of accumulated heavy metals, consequently causing their circulation in waters, organisms, soil and air. (Ayandiran et al. 2010)

Concerning the toxicity, metal and metalloid ions in environment are usually divided in nontoxic for environment, toxic and accessible, and toxic with no or low solubility. Solubility is in direct correlation with toxicity. The most dangerous metals and metalloids are $\mathrm{Cd}, \mathrm{Pb}, \mathrm{Sn}, \mathrm{As}, \mathrm{Hg}$ and $\mathrm{Se}$ cations with high toxicity at low concentrations, while $\mathrm{Cu}, \mathrm{Zn}, \mathrm{Co}, \mathrm{Mn}, \mathrm{Ni}$ and $\mathrm{Fe}$ cations are toxic above certain concentrations. (Järup 2003) The threshold limits, surface waters limits and the health impact of selected heavy metals (nickel, copper, iron and manganese) are presented in Table $\mathbf{1 .}$

Nickel is a transition element, and in environment its most abundant form are Ni(II) based chemical compounds (sulphates, chlorides, carbonates) with high biological availability. Nickel ions can form complexes with organic and inorganic ligands. Nickel ions with humic and fulvic acids can form medium stable complexes. Environmental nickel pollution originates from the dust formed from the soil and rock erosion, volcanic activity, industrial dust, fossil fuel emission, agricultural fields rinsing, traffic emissions, wastewaters and metallurgy. (Merian et al. 2004)

Copper ions in water originate from the rock erosion, industrial waste waters (heavy metal production facilities, incineration plants, smelters, etc.) and from the agricultural land fields rinsing (pesticides). Copper compounds in 
water appear in a solid insoluble form and in a form of a complex compounds. (Martínez \& Motto 2000) The most common forms are $\mathrm{CuCl}_{2}, \mathrm{Cu}(\mathrm{OH})_{2}, \mathrm{CuSO}_{4}$ and $\mathrm{CuCO}_{3}$. Minerals in small fraction sediments have a high affinity to adsorb the copper ions. Copper ions tend to form complex with dissolved humic acids, carbonates and mineral clays, which has a high impact on the nickel behaviour in water. (Merian et al. 2004)

Iron is a transitional element wide spreaded in soil and rocks in a form of silicates, sulphides, oxides and other salts. Iron is usually found in a Fe(II) and Fe(III) form. Fe(II) ions have a moderate mobility, while Fe(III) ions are not mobile. Iron ions mobility is increasing in reducing systems and when $\mathrm{pH}$ is decreasing. Solubility, mobility and oxidation state directly depend on the redox system where they appear. In oxidizing environment appears the oxidation of $\mathrm{Fe}(\mathrm{II})$ to $\mathrm{Fe}(\mathrm{III})$ consequently resulting in the precipitation of it's hydroxides and formation of colloidal suspension. Colloidal Fe(III) can be often found in surface waters. In acidic and reducing conditions $\mathrm{Fe}(\mathrm{II})$ is very soluble. With increasing $\mathrm{pH}$ and the redox potential, iron concentration is increasing and precipitation is more intense. (Merian et al. 2004)

Manganese a transitional element often found in ground waters originating from the soil and rocks. Higher manganese concentrations in waters are caused by anthropogenic activities. In surface waters, manganese is found in soluble or suspended form. This depends on $\mathrm{pH}$, anions in surrounding, redox potential, etc. (Merian et al. 2004) The mobility is increased by lower $\mathrm{pH}$. Usually manganese appears in oxidized from as $\mathrm{MnO}_{2}$. $\mathrm{MnO}_{2}$ is insoluble and precipitates in the sediment. Manganese often appears with iron ions, but in lower concentration as iron.

There is a variety of different analytical techniques for quantitative detection of dissolved copper, nickel, iron and manganese ions in water. Some of them are UV-Vis spectroscopy, ion chromatography, Atomic absorption spectroscopy, Atomic emission spectroscopy, inductively coupled plasma emission spectroscopy, etc. (Stencel \& Jaffe 1996; Zeiner et al. 2007).

Table 1. Permitted heavy metal concentrations and their influence on human health (Fergusson 1991)

\begin{tabular}{|c|c|c|c|c|}
\hline $\begin{array}{l}\text { Heavy } \\
\text { metal }\end{array}$ & $\begin{array}{l}\text { Threshold } \\
\text { limit value }\end{array}$ & $\begin{array}{c}\text { Limit values for surface } \\
\text { waters }\end{array}$ & Target organs & Clinical issues \\
\hline Nickel & $20 \mu \mathrm{g} / 1$ & $0.5 \mathrm{mg} / \mathrm{l}$ & Lungs, skin & $\begin{array}{l}\text { Cancer, } \\
\text { dermatitis }\end{array}$ \\
\hline Copper & $2 \mathrm{mg} / 1$ & $0.5-1.0 \mathrm{mg} / 1$ & $\begin{array}{l}\text { Kidneys, nervous } \\
\text { system }\end{array}$ & Wilson's disease \\
\hline Iron & $200 \mu \mathrm{g} / 1$ & $200 \mu \mathrm{g} / 1$ & $\begin{array}{c}\text { Cardiovascular and } \\
\text { immunological system, } \\
\text { skin }\end{array}$ & $\begin{array}{c}\text { Alzheimer's } \\
\text { disease, anaemia }\end{array}$ \\
\hline Manganese & $50 \mu \mathrm{g} / 1$ & $2 \mathrm{mg} / \mathrm{l}$ & Nervous system & $\begin{array}{l}\text { Central and } \\
\text { peripheral } \\
\text { neuropathy }\end{array}$ \\
\hline
\end{tabular}

The Water Framework Directive (WFD) (2000/60/EC) is the fundamental key document for the water management within European Union countries. WFD includes guidelines for water protection, water management and water quality enhancement, including water resources, surface waters, ground waters, etc. WFD is incorporated in the Croatian legislation through the Law on waters (NN 153/09, 130/11, 56/13, 14/14, 46/18) and a Directive for the standard water quality (NN 73/13).

Paragraph 11 in the Directive for the standard water quality (NN 73/13) divides the surface waters based on their ecological quality parameters in:

1. very good ecological condition,

2. good ecological condition,

3. medium ecological condition,

4. low ecological condition and

5. very low ecological condition.

Monitoring of the surface waters is carried out as a: surveillance monitoring (long-term changes), operational monitoring (changes during treatment of bad water quality areas) and research monitoring (detection of unknown relations). 


\section{MATERIAL AN METHODS}

All samplings and analytical measurements were performed by the Public health Institute of Varaždin county as a part of the river waters monitoring plan from 2016 to 2021 within the long term river waters monitoring plan for the north-west Croatia carried out by the Public health Institute of Varaždin county.

\subsection{Sampling locations}

The sampling locations were placed in the north-west region of Croatia in three counties: Međimurska, Varaždinska and Krapinsko-Zagorska. The rivers on the northern part flow into the Drava river, and rivers on the southern part of the region flow into the Sava river. All the rivers belong to the Danube water area, and Black Sea basin.

River Drava is characterised by the nival hydrological regime (max. flow in June, min. in December), while selected smaller rivers have pluvial hydrological regime (max. flow in March/April) with lower hydrological characteristics compared to Drava. River Sava is characterised as a Peripannonian pluvial-nival type of discharge regime in the upstream river part where the samples were collected, while the downstream discharge regime in the downstream part on the Bosnian border is characterized as a Pannoninan pluvial-nival type. (Orešić et al. 2017)

The sampling locations in Figure 1 are marked on the Croatian river map obtained from the Hrvatske vode company. The north-west region was magnified for clarity, and it includes all three counties where the sampling was performed.

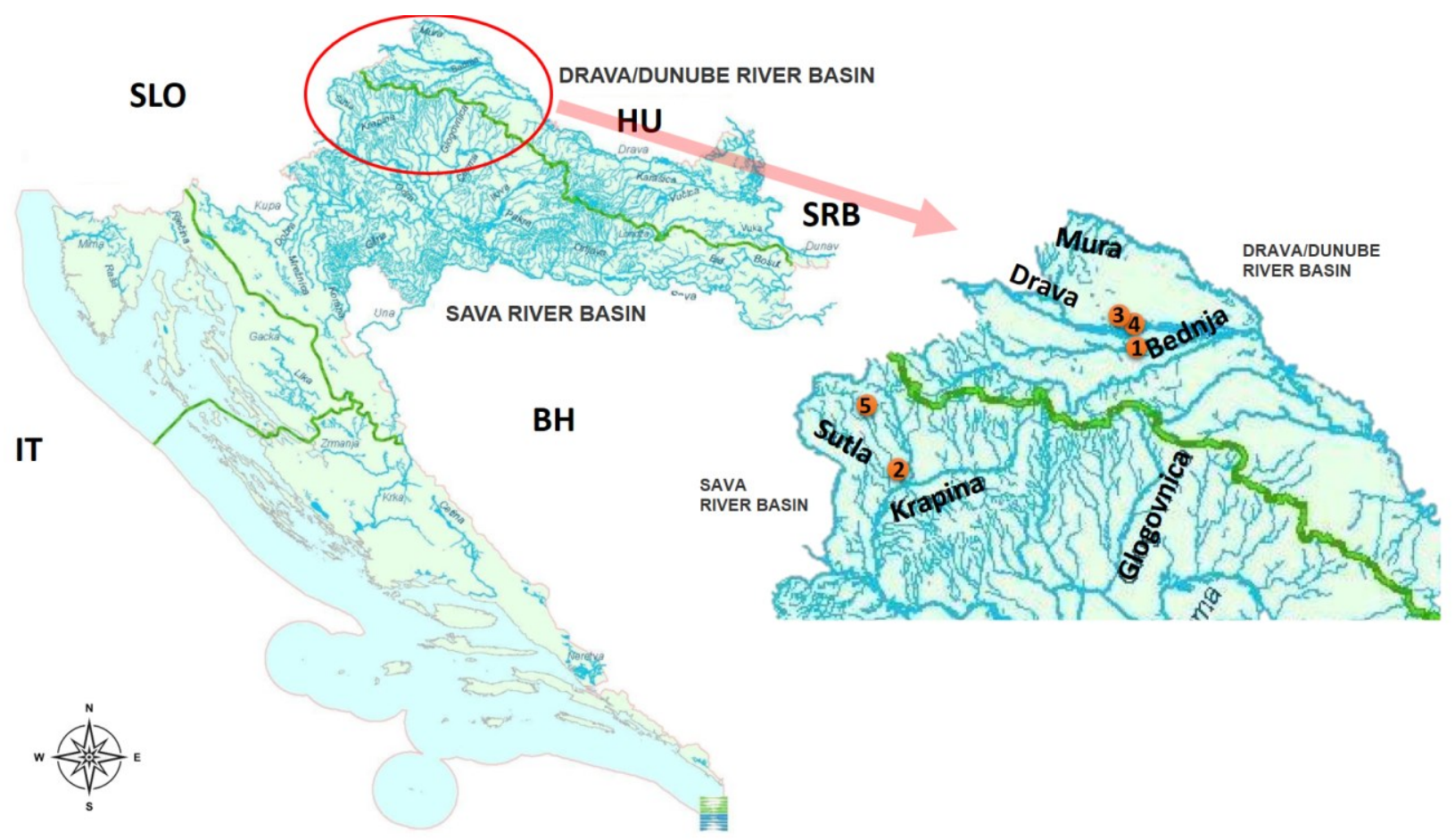

Figure 1. Croatian river map on the left; and a magnified north-west region with the sampling locations and location numbering on the right.

The river sampling locations are:

1. Plitvice, Zbela - Plitvica river before Zbela bayou (coordinates: 490826 X HTRS, 5125398 Y HTRS) flows into the Drava river.

2. Horvatska, Veliko Trgovišće - Horvatska river, at Veliko trgovišće (coordinates: $450139 \mathrm{X}$ HTRS, 5096157 Y HTRS) flows into the Sava river.

3. Melačka, Vularija - Melačka river, at Vularija (coordinates: 498809 X HTRS, 5130717 Y HTRS) flows into the Drava river.

4. HE Čakovec, Štefanec - Lower circumferential channel of the water storage reservoir at Čakovec/Štefanec dam (coordinates: 497381 X HTRS, 5129590Y HTRS) flows into the Drava river.

5. Kostejina, Jalšje - Kosteljina river, at Jalšje (coordinates: 449845 X HTRS, 5099703 Y HTRS) flows into the Sava river. 


\subsection{Sampling}

Sampling was performed according to the water sampling regulation ISO 5667-6 „Guidance on sampling of rivers and streams“ (5667-6 ISO). Sampling was performed manually, about $15 \mathrm{~cm}$ beneath the water surface, and the sample was collected directly into the $1000 \mathrm{ml}$ sampling glass bottles with the bottleneck turned to the water stream (Figure 2). At each location one sample was taken. The samples were stored at $4{ }^{\circ} \mathrm{C}$ and transferred to the laboratory. Next, the samples were filtrated trough $0.45 \mu \mathrm{m}$ filter paper and the filtrate was transferred to the 50 $\mathrm{ml}$ plastic bottles, and ready for measurements. Measuring the dissolved fraction of metals has allowed us to estimate the quantities of the bioavailable heavy metals.

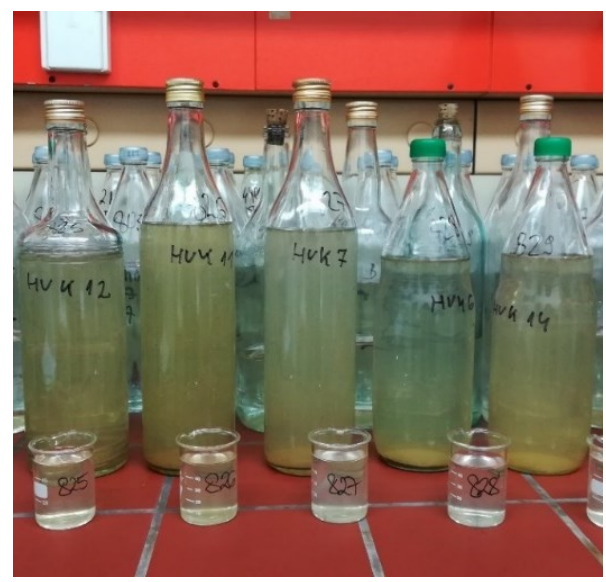

Figure 2. River water samples from the selected locations in north-west Croatia.

\subsection{Measuring setup, chemicals and procedure}

The samples were analysed by the ion chromatography instrument Dionex DX 500 (Thermo Scientific, USA). The quantification limit of the method was $5 \mu \mathrm{g} / \mathrm{l}$ with $15 \%$ uncertainty. The programme for data acquisition was Chromeleon 6.80. The IonPac CS5A was used as a separation column and the CG5A was used as a guard preseparation column. As an eluent, the MetPac PDCA eluent (Thermo Scientific, USA) with $66 \mathrm{mM}$ potassium hydroxide and a $74 \mathrm{mM}$ formic acid was used. $200 \mathrm{ml}$ of the PDCA eluent was diluted with $1000 \mathrm{ml}$ ultrapure water. Dionex 4-(2-Pyridylazo) resorcinol monosodium salt (PAR) (Thermo Scientific, USA) is used for post column derivatization of transition metals separated in the separation column together with the Dionex MetPAC PAR Post Column Diluent (1 M 2dimethylaminoethanol, 0.5 M ammonium hydroxide, 0.3 M sodium bicarbonate) (Thermo Scientific, USA). To prepare the post-column reagent, $0.05 \mathrm{~g}$ of 4-(2-Pyridylazo) resorcinol monosodium salt was dissolved in $250 \mathrm{ml}$ MetPa PAR post column diluent.

Other measuring conditions were as follows: flow speed $-1.2 \mathrm{ml} / \mathrm{min}$, injected sample volume - $50 \mu 1$, speed of the reagent $-0.6 \mathrm{ml} / \mathrm{min}$, wavelength of the detector $-530 \mathrm{~nm}$. As a calibration standard ICP multi-element standard solution IV - Certified reference material (Merck, Germany) with $200 \mu \mathrm{g} / \mathrm{l}$ concentration of heavy metals was used as a reference.

\section{RESULTS AND DISCUSSION}

The content of heavy metals was measured at 5 locations of the river waters in the north-west of Croatia in the period of 2016 to 2018. The samples were taken periodically or every month during this period.

Copper content was measured at two locations: Plitvica river, near Zbela in Varaždinska county and Horvatska, near Veliko Trgovišće in Krapinsko-Zagorska county, in the period from 2016 to 2018 (Table 2).

At the Plitvica river, near Zbela the concentrations of the $\mathrm{Cu}$ are below $5 \mu \mathrm{g} / \mathrm{l}$, and at the Horvatska, near Veliko Trgovišće the concentrations of the $\mathrm{Cu}$ are below $5 \mu \mathrm{g} / \mathrm{l}$, except in August 2018 when the concentration was 7.4 $\mu \mathrm{g} / \mathrm{l}$ and in October 2018 when the concentration was $7.6 \mu \mathrm{g} / \mathrm{l}$.

In the Regulation on Water Quality Standard NN 80/2018 (Uredba o standardu kakvoće voda, NN 73/13; $151 / 14 ; 78 / 15 ; 61 / 16 ; 80 / 18)$ the Average Annual Concentrations (AAC) for the copper compounds in surface waters is from 1.1 to $8.8 \mu \mathrm{g} / \mathrm{l}$. Copper concentrations at both locations were within the prescribed concentrations.

Nickel content was measured at two locations: Melačka river, near Vularija in Međimurje county and HE Čakovec dam, near Štefanec in Međimurje county, in the period from 2016 to 2018 (Table 3).

At the Melačka river, near Vularija the concentrations of the Ni are below $5 \mu \mathrm{g} / \mathrm{l}$, and at the HE Cakovec dam, near Štefanec the concentrations of the Ni are also below $5 \mu \mathrm{g} / \mathrm{l}$, in the measured period

The Regulation on Water Quality Standard NN 80/2018 (Uredba o standardu kakvoće voda, NN 73/13; 151/14; $78 / 15 ; 61 / 16 ; 80 / 18$ ) defined $34 \mu \mathrm{g} / 1$ as a Maximum Annual Concentrations (MAC) for nickel and nickel 
compounds in surface waters, and $4 \mu \mathrm{g} / \mathrm{l}$ as an Average Annual Concentrations (AAC) in a sense of the bioavailability. Nickel concentrations at both locations were within the prescribed concentrations.

Table 2. Dissolved copper concentrations at selected locations in the period from 2016 to 2018.

\begin{tabular}{|c|c|c|c|c|c|c|}
\hline & \multicolumn{6}{|c|}{ DISSOLVED COPPER CONCENTRATION $(\mu \mathrm{g} / \mathrm{l})$} \\
\hline & \multicolumn{6}{|c|}{ LOCATION } \\
\hline & \multicolumn{3}{|c|}{ Plitvica, Zbela } & \multicolumn{3}{|c|}{ Horvatska, Veliko Trgovišće } \\
\hline & 2016 & 2017 & 2018 & 2016 & 2017 & 2018 \\
\hline January & I & 1 & $<5$ & l & I & $<5$ \\
\hline February & $<5$ & l & $<5$ & $<5$ & l & $<5$ \\
\hline March & $<5$ & l & $<5$ & $<5$ & l & $<5$ \\
\hline April & $<5$ & / & $<5$ & $<5$ & / & $<5$ \\
\hline May & $<5$ & $<5$ & $<5$ & $<5$ & $<5$ & / \\
\hline June & $<5$ & $<5$ & $<5$ & $<5$ & $<5$ & $<5$ \\
\hline July & $<5$ & $<5$ & $<5$ & $<5$ & $<5$ & $<5$ \\
\hline August & $<5$ & / & $<5$ & $<5$ & $<5$ & 7,4 \\
\hline September & $<5$ & $<5$ & $<5$ & $<5$ & $<5$ & $<5$ \\
\hline October & $<5$ & $<5$ & $<5$ & $<5$ & / & 7,6 \\
\hline November & $<5$ & / & $<5$ & $<5$ & $<5$ & $<5$ \\
\hline December & $<5$ & $<5$ & $<5$ & $<5$ & $<5$ & $<5$ \\
\hline
\end{tabular}

Table 3. Dissolved nickel concentrations at selected locations in the period from 2016 to 2018.

\begin{tabular}{|c|c|c|c|c|c|c|}
\hline & \multicolumn{6}{|c|}{ DISSOLVED NICKEL CONCENTRATION $(\mu \mathrm{g} / \mathrm{l})$} \\
\hline & \multicolumn{6}{|c|}{ LOCATION } \\
\hline & \multicolumn{3}{|c|}{ Melačka, Vularija } & \multicolumn{3}{|c|}{ HE Čakovec, Štefanec } \\
\hline & 2016 & 2017 & 2018 & 2016 & 2017 & 2018 \\
\hline January & / & / & $<5$ & / & l & $<5$ \\
\hline February & / & / & / & / & / & $<5$ \\
\hline March & / & / & $<5$ & / & / & $<5$ \\
\hline April & / & / & $<5$ & / & / & $<5$ \\
\hline May & / & $<5$ & / & / & $<5$ & $<5$ \\
\hline June & / & $<5$ & I & I & $<5$ & $<5$ \\
\hline July & / & / & I & / & $<5$ & $<5$ \\
\hline August & 1 & / & / & I & $<5$ & $<5$ \\
\hline September & / & $<5$ & $<5$ & I & $<5$ & $<5$ \\
\hline October & / & $<5$ & $<5$ & / & $<5$ & $<5$ \\
\hline November & / & $<5$ & $<5$ & l & $<5$ & $<5$ \\
\hline December & / & $<5$ & / & 1 & $<5$ & $<5$ \\
\hline
\end{tabular}

Copper, manganese and iron content was measured Kosteljina river, near Jalšje at the Krapinsko-Zagorska county, in the period from 2016 to 2018 (Table 4).

The concentrations of the $\mathrm{Cu}$ are below $5 \mu \mathrm{g} / \mathrm{l}$, except of August $2018(7.4 \mu \mathrm{g} / \mathrm{l})$ and October $2018(7.6 \mu \mathrm{g} / \mathrm{l})$. Since Kosteljina is a left bayou of the Horvatska river, there is a correlation between the concentrations of copper in both rivers. In fact, measured concentrations are the same. When tracking the pollution source, it can be concluded that the pollution is probably somewhere on the Kosteljina river upper stream. 
The concentrations of the $\mathrm{Mn}$ in 2016 are below $5 \mu \mathrm{g} / \mathrm{l}$, except in February $(9.7 \mu \mathrm{g} / \mathrm{l})$ and June $(8.5 \mu \mathrm{g} / \mathrm{l})$. During 2017 the concentrations of Mn were higher than $5 \mu \mathrm{g} / \mathrm{l}$, starting from June $(150 \mu \mathrm{g} / \mathrm{l})$ and decreasing up to September $(5.2 \mu \mathrm{g} / \mathrm{l})$. Usually, the Mn ions appear together with Fe ions. During 2018 the concentration of Mn was below $5 \mu \mathrm{g} / \mathrm{l}$, except in February $(10 \mu \mathrm{g} / \mathrm{l})$, June $(92.5 \mu \mathrm{g} / \mathrm{l})$, August $(116 \mu \mathrm{g} / \mathrm{l})$ and October $(7.7 \mu \mathrm{g} / 1)$.

The lowest concentration of the Fe in 2016 was in March $(133.5 \mu \mathrm{g} / \mathrm{l})$ and the highest were in August (2415 $\mu \mathrm{g} / \mathrm{l})$ and November $(2880 \mu \mathrm{g} / \mathrm{l})$. The lowest concentration of the Fe in 2017 was in December $(142 \mu \mathrm{g} / \mathrm{l})$ and the highest was in August $(1618 \mu \mathrm{g} / \mathrm{l})$ and November $(2880 \mu \mathrm{g} / \mathrm{l})$. The lowest concentration of the Fe in 2018 was in January $(152 \mu \mathrm{g} / \mathrm{l})$ and the highest was in July $(1832 \mu \mathrm{g} / \mathrm{l})$. For this location, higher Mn values are present in the second part of the year for all three observed years.

Higher concentrations of iron and manganese could be explained by the higher agricultural activity in the area, higher industrial activities during summer months and potentially by the low coverage of the sewerage system in this area.

When compared with the Mn concentrations summer months obtained higher ion concentrations than usual. The Regulation on Water Quality Standard NN 80/2018 (Uredba o standardu kakvoće voda (NN 73/13; 151/14; $78 / 15$; 61/16; 80/18) did not defined the Maximum Annual Concentrations (MAC) or Average Annual Concentrations (AAC) for manganese and iron ions. In this way, there is no criteria for water classification. According to available data on selected heavy metal ions concentration in the period from 2016 to 2018 it can be concluded that surface waters at selected locations obtained different pollution levels.

Varaždin county and Međimurje county obtained selected heavy metal ions concentration within the acceptable limits and these waters can be considered not to be polluted. On the other hand, Krapinsko-Zagorska county obtained selected heavy metal ions concentration higher then acceptable limits and could be considered as medium polluted with higher anthropogenic influence. Further monitoring should be carried out to prevent possible higher anthropogenic impact.

Table 4. Dissolved copper, manganese and iron concentrations at Kosteljina river, Jalšje in the period from 2016 to 2018

\begin{tabular}{|c|c|c|c|c|c|c|c|c|c|}
\hline & \multicolumn{9}{|c|}{ LOCATION: Kosteljina, Jalšje } \\
\hline & \multicolumn{3}{|c|}{ DISSOLVED Cu $(\mu \mathrm{g} / \mathrm{l})$} & \multicolumn{3}{|c|}{ DISSOLVED Mn $(\mu \mathrm{g} / \mathrm{l})$} & \multicolumn{3}{|c|}{ DISSOLVED Fe $(\mu \mathrm{g} / \mathrm{l})$} \\
\hline & 2016 & 2017 & 2018 & 2016 & 2017 & 2018 & 2016 & 2017 & 2018 \\
\hline January & l & / & $<5$ & / & / & $<5$ & / & l & 152 \\
\hline February & $<5$ & l & $<5$ & 9.7 & / & 10.8 & 803 & l & 256 \\
\hline March & $<5$ & 1 & $<5$ & $<5$ & / & $<5$ & 133 & l & 440 \\
\hline April & $<5$ & l & $<5$ & $<5$ & / & $<5$ & 383 & l & 210 \\
\hline May & $<5$ & l & / & $<5$ & / & $<5$ & 183 & 257 & 1072 \\
\hline June & $<5$ & $<5$ & $<5$ & 8.5 & 150 & 92.5 & 440 & 754 & 591 \\
\hline July & $<5$ & $<5$ & $<5$ & $<5$ & 81.1 & $<5$ & 656 & 556 & 1832 \\
\hline August & $<5$ & $<5$ & 7,4 & $<5$ & 50 & 116 & 2415 & 1618 & 583 \\
\hline September & $<5$ & $<5$ & $<5$ & $<5$ & 5.2 & $<5$ & 481 & 722 & 708 \\
\hline October & $<5$ & $<5$ & 7,6 & $<5$ & $<5$ & 7.7 & 896 & 268 & 1132 \\
\hline November & $<5$ & $<5$ & $<5$ & $<5$ & $<5$ & $<5$ & 2880 & 581 & 261 \\
\hline December & $<5$ & $<5$ & $<5$ & $<5$ & $<5$ & $<5$ & 345 & 142 & 353 \\
\hline
\end{tabular}

\section{CONCLUSION}

Concentrations of dissolved nickel measured at Melačka river, near Vularija in Međimurje county and HE Čakovec dam, near Štefanec in Međimurje county, in the period from 2016 to 2018 were below $5 \mu \mathrm{g} / \mathrm{l}$ and could be considered as not polluted.

Concentrations of dissolved copper measured at Plitvica river, near Zbela in Varaždin county and Horvatska, near Veliko Trgovišće in Krapinsko-Zagorska county, in the period from 2016 to 2018, were mostly below $5 \mu \mathrm{g} / 1$ and could be considered as not polluted.

At Kosteljina river near Jalšje at the Krapinsko-Zagorska county, in the period from 2016 to 2018. concentrations of dissolved copper were mostly below $5 \mu \mathrm{g} / \mathrm{l}$; concentrations of dissolved manganese and iron were higher especially during second part of the year, with some fluctuations. For this reason, Kosteljina river could be considered as medium polluted. 


\section{ACKNOWLEDGEMENT}

Authors would like to express their gratitude to the Croatian Institute of Public Health in Varaždin county.

\section{REFERENCES}

Tolulope A, Fawole O, Akinloye OM (2010) Bioconcentration of metals in the head capsule and skeleton of Clarias gariepinus exposed to sublethal concentrations of soap and detergent effluents. Agriculture and Biology Journal of North America doi: 10.5251/abjna.2010.1.5.796.802.

Direktva 2000/60/EC Europskog parlamenta i vijeća. Hrvatske vode. 2001.

Fergusson, J. E. (1991) The heavy elements : chemistry, environmental impact and health effects. New York: Oxford.

Järup L (2003) Hazards of heavy metal contamination. British Medical Bulletin doi: 10.1093/bmb/ldg032.

Jordana S, Batista Piera E. (2004) Natural groundwater quality and health. Geologica Acta doi: https://doi.org/10.1344/105.000001438.

Martínez C, Motto H (2000) Solubility of lead, zinc and copper added to mineral soils. Environmental Pollution doi: 10.1016/S0269-7491(99)00111-6.

E. Merian E, Anke M, Ihnat M, Stoeppler M (2004) Elements and their Compounds in the Environment:

Occurrence, Analysis and Biological Relevance, 2nd edn. WILEY-VCH Verlag GmbH, Weinheim

Orešić D, Čanjevac I, Maradin M (2017) Changes In Discharge Regimes In The Middle Course Of The Sava River In The 1931 - 2010 Period. Prace Geograficzne doi : 10.4467/20833113PG.17.024.8036

Stencel JR, Jaffe PR (1996) Trace metal analysis using ion chromatography in water partitioned from crudeoil spills. Transactions on Ecology and the Environment 11:223-230.

Uredba o standardu kakvoće voda (NN 73/13; 151/14; 78/15; 61/16; 80/18)

Wood JM (1974) Biological Cycles for Toxic Elements in the Environment. Science doi: 10.1126/science.183.4129.1049.

Zeiner M, Rezić I, Steffan (2007) Analytical Methods for the Determination of Heavy Metals in the Textile Industry. Kemija u industriji 56:587-595. 